\title{
Variations in Lake Levels during the Holocene in North America: An Indicator of Changes in Atmospheric Circulation Patterns
}

\author{
Les variations de niveaux lacustres au cours de l'Holocene, en \\ Amérique du Nord : un indicateur de changement dans la \\ circulation atmosphérique \\ Variationen in der Höhe der Seen-Wasserspiegel während des \\ Holozän in Nordamerika: ein Indikator für Veränderungen in \\ der atmosphärischen Bewegung
}

\author{
S. P. Harrison et S. E. Metcalfe
}

Volume 39, numéro 2, 1985

Tendances climatiques à l’Holocène en Amérique du Nord

URI : https://id.erudit.org/iderudit/032598ar

DOI : https://doi.org/10.7202/032598ar

Aller au sommaire du numéro

Éditeur(s)

Les Presses de l'Université de Montréal

ISSN

0705-7199 (imprimé)

1492-143X (numérique)

Découvrir la revue

Citer cet article

Harrison, S. P. \& Metcalfe, S. E. (1985). Variations in Lake Levels during the Holocene in North America: An Indicator of Changes in Atmospheric Circulation Patterns. Géographie physique et Quaternaire, 39(2), 141-150. https://doi.org/10.7202/032598ar

\section{Résumé de l'article}

Les fluctuations de superficie enregistrées dans les lacs fermés fournissent des données détaillées quant aux variations, aux échelles régionale et continentale, du bilan annuel moyen de l'eau. On a reconstitué, en Amérique du Nord, la chronologie des fluctuations survenues à l'Holocène, en se fondant sur les données fournies par le Oxford Lake-Level Data Bank. Cette banque de données renseigne sur 67 bassins lacustres, situés en Amérique au nord de l'équateur. On présente ici des cartes illustrant les niveaux lacustres entre 10 000 et 0 ans BP. L'Holocène inférieur se caractérisait par une progression de l'aridité qui a entraîné un abaissement général du niveau des lacs situés sous les moyennes latitudes, environ 9000 ans BP. Environ 6000 ans BP. cette zone passait du $32^{\circ}$ de latitude nord au $51^{\circ}$. Un grand nombre de particularités qui caractérisent aujourd'hui les niveaux lacustres, notamment les hauts niveaux qu'on observe au nord du $46^{\circ} \mathrm{N}$ et le long de la côte est, étaient déjà acquises vers 3000 ans BP. Quatre types d'évolution générale se dégagent au cours des millénaires. Par ailleurs, on présente des histogrammes illustrant les niveaux lacustres selon une échelle temporelle de $10^{3}-10^{4}$ ans. On considère que les changements qu'ont connu, en Amérique du Nord, les niveaux lacustres révèlent qu'il y a eu déplacement des composantes principales de la circulation atmosphérique générale, surtout en ce qui a trait aux vents d'ouest et à la dépression équatoriale. Ils se sont traduits par des modifications de la trajectoire des masses d'air, ce qui explique la position des limites de masses d'air sur le continent. 


\title{
VARIATIONS IN LAKE LEVELS DURING THE HOLOCENE IN NORTH AMERICA: AN INDICATOR OF CHANGES IN ATMOSPHERIC CIRCULATION PATTERNS
}

\author{
S.P. HARRISON and S.E. METCALFE, School of Geography, Mansfield Road, Oxford 0X1 3TB, United Kingdom.
}

\begin{abstract}
Fluctuations in the extent of closed lakes provide a detailed record of regional and continental variations in mean annual water budget. The temporal sequence of hydrological fluctuations during the Holocene in North America has been reconstructed using information from the Oxford Lake-Level Data Bank. This data base includes 67 basins from the Americas north of the equator. Maps of lake status, an index of relative depth, are presented for the period 10,000 to $0 \mathrm{yr}$ BP. The early Holocene was characterised by increasingly arid conditions, which led to widespread low lake levels in the mid-latitudes by $9,000 \mathrm{yr}$ BP. By $6,000 \mathrm{yr}$ BP this zone of low lakes extended from $32^{\circ}$ to $51^{\circ} \mathrm{N}$. Many of the features of the present day lake-level pattern, particularly high lake levels north of $46^{\circ} \mathrm{N}$ and along the eastern seaboard, were established by 3,000 yr BP. Four distinctive regional patterns of lake behaviour through time are apparent. Histograms of lake status from 20,000 to $0 \mathrm{yr}$ BP are presented for each of these regions. They illustrate the temporal patterns of lake-level fluctuations on a time scale of $10^{3}-10^{4} \mathrm{yr}$. Changes in lake status over North America are interpreted as indicating displacements in major features of the general circulation, specifically the zonal Westerlies and the Equatorial Trough, as reflected by changes in air mass trajectories and hence the position of air mass boundaries over the continent.
\end{abstract}

RÉSUMÉ Les variations de niveaux lacustres au cours de l'Holocène, en Amérique du Nord: un indicateur de changement dans la circulation atmosphérique. Les fluctuations de superficie enregistrées dans les lacs fermés fournissent des données détaillées quant aux variations, aux échelles régionale et continentale, du bilan annuel moyen de leau. On a reconstitué, en Amérique du Nord, la chronologie des fluctuations survenues à l'Holocène, en se fondant sur les données fournies par le Oxford Lake-Level Data Bank. Cette banque de données renseigne sur 67 bassins lacustres, situés en Amérique au nord de l'équateur. On présente ici des cartes illustrant les niveaux lacustres entre 10000 et 0 ans BP. L'Holocène inférieur se caractérisait par une progression de l'aridité qui a entraîné un abaissement général du niveau des lacs situés sous les moyennes latitudes, environ 9000 ans BP. Environ 6000 ans BP, cette zone passait du $32^{\circ}$ de latitude nord au $51^{\circ}$. Un grand nombre de particularités qui caracterisent aujourd'hui les niveaux lacustres, notamment les hauts niveaux qu'on observe au nord du $46^{\circ} \mathrm{N}$ et le long de la côte est, étaient déjà acquises vers 3000 ans BP Quatre types d'évolution générale se dégagent au cours des millénaires. Par ailleurs, on présente des histogrammes illustrant les niveaux lacustres selon une échelle temporelle de $10^{3}-10^{4}$ ans. On considère que les changements qu'ont connu, en Amérique du Nord, les niveaux lacustres révèlent qu'il y a eu déplacement des composantes principales de la circulation atmosphérique générale, surtout en ce qui a trait aux vents d'ouest et à la dépression équatoriale. lls se sont traduits par des modifications de la trajectoire des masses d'air, ce qui explique la position des limites de masses d'air sur le continent.
ZUSAMMENFASSUNG Variationen in der Höhe der Seen-Wasserspiegel während des Holozän in Nordamerika: ein Indikator für Veränderungen in der atmosphärischen Bewegung. Schwankungen in der Ausdehnung geschlossener Seen liefern einen detaillierten Nachweis über regionale und kontinentale Variationen im durchschnittlichen jährlichen Wasser-Budget. Man hat die zeitliche Abfolge von Wasserschwankungen während des Holozän in Nordamerika rekonstruiert, gestützt auf Informationen von der Oxford Lake-Level Data Bank. Diese Daten-Bank umfaßt 67 Wasserbecken Amerikas, die nörlich vom Äquator liegen. Für die Zeit von 10000 bis O v.u.Z. werden Karten vorgelegt, die über die relative Tiefe der Seen informieren. Das frühe Holozän zeichnete sich durch zunehmend trockene Bedingungen aus, was um 9000 v.u.Z. in den mittleren Breiten $\mathrm{zu}$ weit verbreiteten niedrigen Seewasserspiegeln führte. Um 6000 v.u.Z. dehnte sich diese Zone niedriger Wasserspiegel von $32^{\circ}$ bis $51^{\circ}$ nördlicher Breite aus. Viele Erscheinungsformen, die die heutigen Seen-Wasserspiegel charakterisieren, insbesondere hohe Seen-Wasserspiegel nördlich von $46^{\circ}$ nördlicher Breite und entlang der Ostküste wurden um 3000 v.u.Z. festgelegt. Durch die Jahrtausende sind vier unterschiedliche regionale Muster des Seen-Verhaltens feststellbar. Für jedes dieser Gebiete werden Histogramme des Seen-Zustandes von 20000 bis O Jahren v.u.Z. vorgelegt. Sie illustrieren die zeitliche Anordnung der SeenWasserspiegelschwankungen auf einer ZeitSkala von $10^{3}-10^{4}$ Jahren. Veränderungen im Seenzustand Nord-amerikas werden interpretiert als Hinweis auf eine Verlagerung der Hauptmerkmale der allgemeinen atmosphärischen Strömungen, insbesondere was die Westwinde des Gebiets und die äquatoriale Windstille betrifft. Das spiegelt sich in Veränderungen der Zugrichtung der Luftmassen und folglich der Position der Luftmassengrenzen über dem Kontinent. 


\section{INTRODUCTION}

Fluctuations in closed lakes, which are particularly sensitive to changes in the balance between precipitation and evaporation, provide a detailed record of variations in regional and continental mean annual water budget (SMITH and STREETPERROTT, 1983; STREET-PERROTT and HARRISON, 1985). The current spatial distribution and relative extent of such lakes can be directly related to the mean position of major features of the atmospheric circulation (STREET-PERROTT and ROBERTS, 1983). Closed lakes are most widespread today in the arid and subhumid regions, particularly in the tropics and subtropics (SCHUILING, 1977). Many lakes in temperate areas, however, ceased to overflow during drier periods of the Late Quaternary in response to changes in both the strength and mean position of major circulation features. Examination of the patterns of lake-level variations therefore provides a method of reconstructing global atmospheric circulation during the Late Quaternary.

In this paper, we describe the spatial and temporal variations in the patterns of lake levels for the Americas north of the Equator, concentrating on the Holocene period. This time span has been chosen because it yields the best coverage of sites with reliable chronologies and good stratigraphical resolution. Previous attempts at reconstructing the palaeoclimates of North America have often had a narrow disciplinary or regional focus. A better understanding of changes in at-

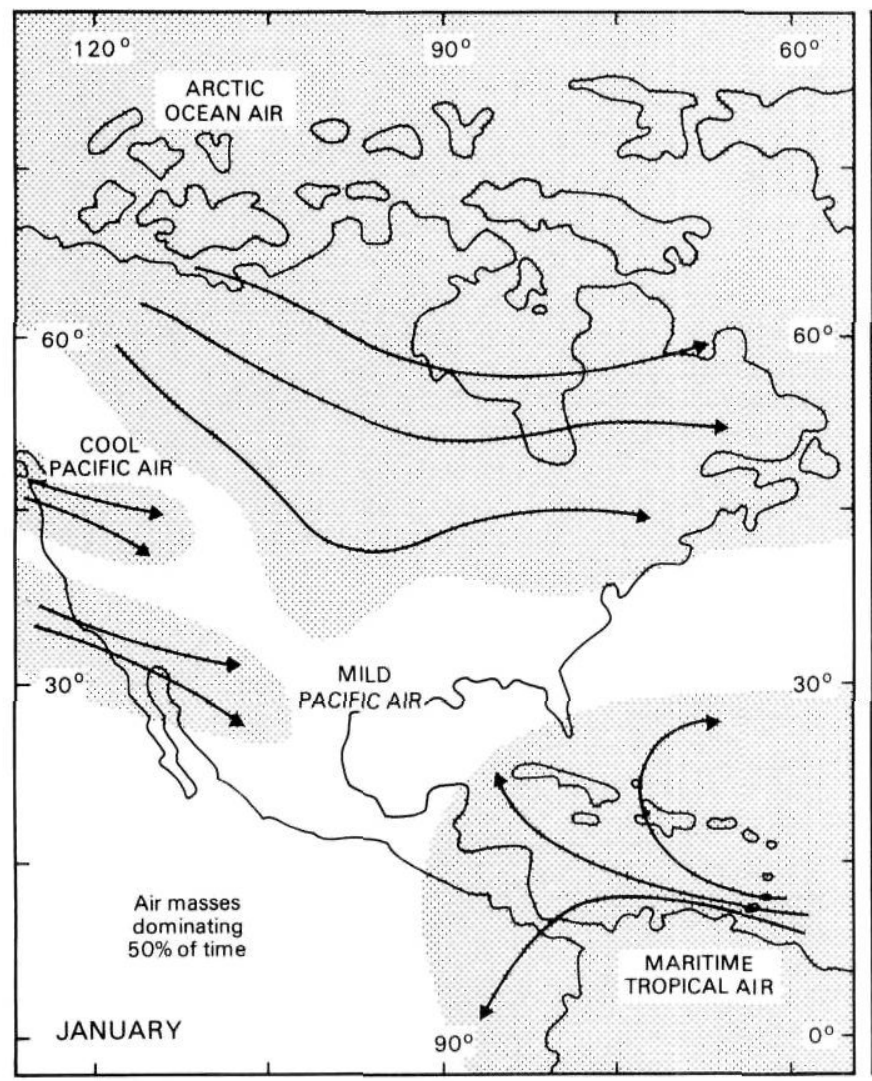

FIGURE 1. Present-day distribution of air masses over North America for January and July. Compiled from data in BRYSON and HARE (1974). mospheric circulation can be achieved by consideration of the palaeorecord at a continental scale (BRYSON and WENDLAND, 1967). With recent improvements in the data coverage for North America, it is now possible to adopt such an approach using lake-level information.

Regional climates of North America can be described in terms of the seasonal distribution of air masses from different sources over the continent (BRYSON, 1966; BRYSON and HARE, 1974; WENDLAND and BRYSON, 1981). Figure 1 shows the distribution of the major air masses during winter (January) and summer (July). In winter, in response to the equatorward displacement of the Equatorial Trough and the zonal Westerlies, the cold, dry Arctic air mass dominates much of North America. Penetration of Pacific air into the continental interior is blocked by the presence of this cold, stable air over the mid-continent. The influence of moist tropical air is also limited. In summer, as the Equatorial Trough and zonal Westerlies move northwards, the influence of the Arctic air mass is reduced and both Pacific and Maritime Tropical air masses penetrate further into the continental interior. There are significant contrasts between the moisture characteristics of these air masses and therefore their distribution can be seen as a major determinant of precipitation over the continent. Since lake behaviour reflects the balance between precipitation and evaporation, the regional patterns of lake levels should be related to air mass distribution. Broadly speaking, high

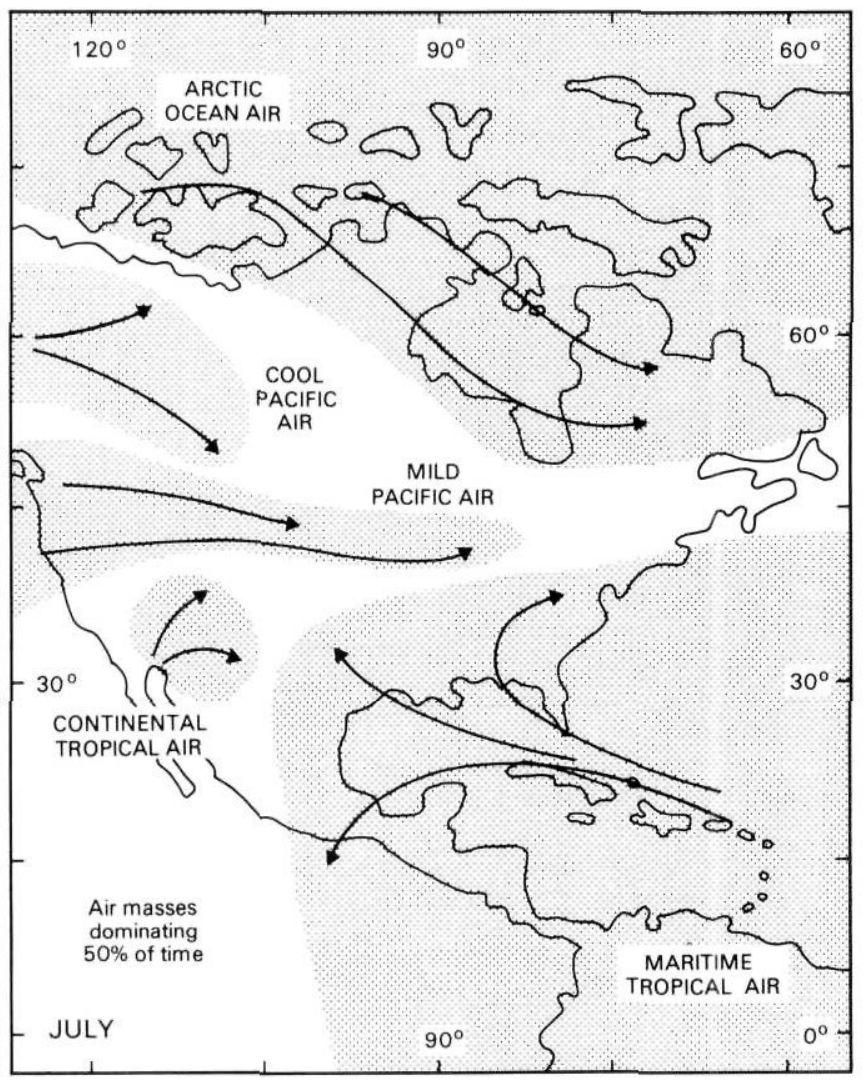

Répartition actuelle des masses d'air au-dessus de l'Amérique du Nord pour janvier et juillet (compilation faite à partir des données contenues dans BRYSON et HARE (1974). 
lake levels are characteristic of the frontal zone between Pacific and Arctic air (Arctic Front) and also the region influenced by moist tropical air. Thus high lake levels are found north of $50^{\circ} \mathrm{N}$ and along the eastern seabord at the present day. The interpretation of spatial patterns of Late Quaternary lake-level fluctuations put forward in this paper is based on this present-day relationship between lake behaviour and major features of the atmospheric circulation as expressed through the distribution of air masses from different sources over the continent.

\section{METHODS}

The temporal sequence of hydrological fluctuations in North America has been reconstructed using information from the Oxford Lake-Level Data Bank. This data base, compiled from published material, contains records of fluctuations in lake level from basins that have been closed during part or all of their Late Quaternary history (STREET and GROVE, 1976 , 1979). Basins where water depth is primarily controlled by changes in sea level, or responds to glacier fluctuations, have been excluded from the data bank. Only sites with a chronology based on ${ }^{14} \mathrm{C}$ or dated tephra layers are included. Lake-level fluctuations are reconstructed from a wide variety of geomorphological, stratigraphical, palaeoecological and archaeological evidence. The data are therefore standardised (STREET-PERROTT et al., 1985) to yield estimates of lake

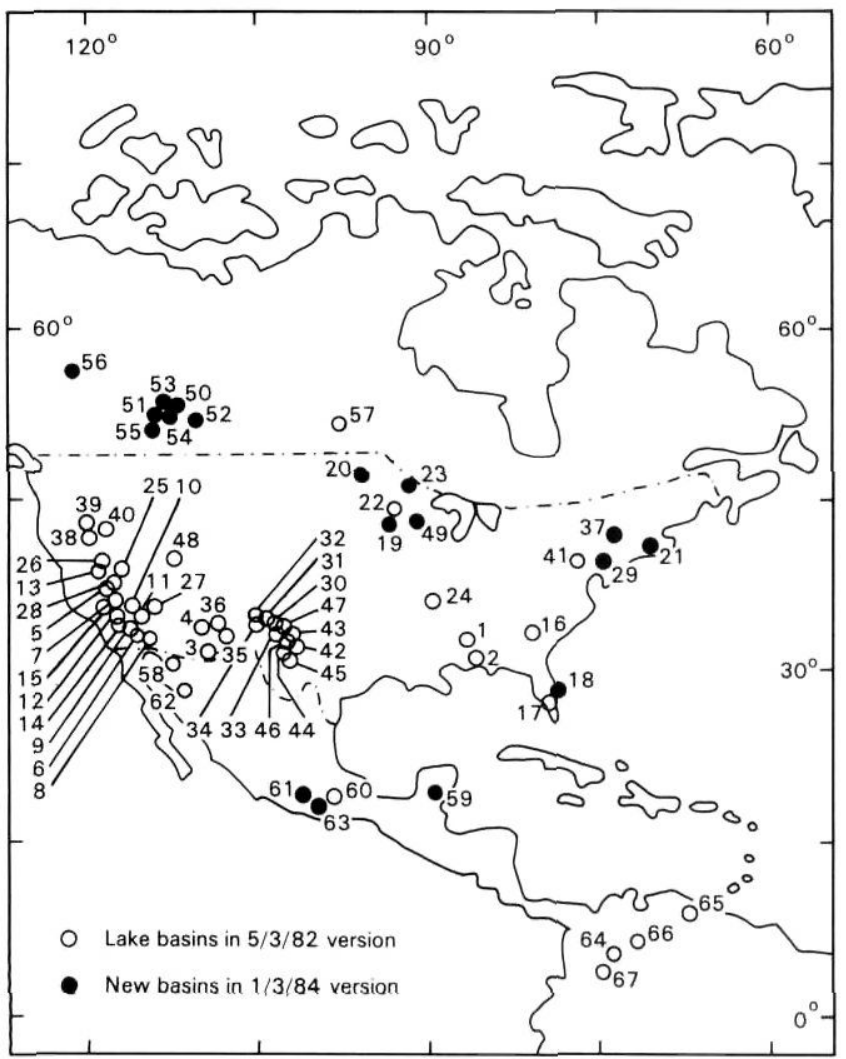

FIGURE 2. The distribution of lake basins used in this study. The numbering system refers to basin numbers in Table I.

Répartition des bassins lacustres traités dans le présent article. La numérotation correspond à celle du tableau $\mathrm{I}$. status, an index of relative depth. The total range of water depth registered within each basin is divided into three status classes (low, intermediate and high), using an arbitrary but consistent set of rules. Status is coded on an ordinal scale at $1000 \mathrm{yr}$ intervals from 30,000 to $0 \mathrm{yr}$ BP (STREET-PERROTT and ROBERTS, 1983; STREET-PERROTT and HARRISON, 1984).

The Oxford Data Bank has recently been revised and substantially expanded (Data Bank Version 1/3/84) and now includes a total of 67 basins (Table I and Fig. 2) from North America (HARRISON and METCALFE, 1985). Twenty-one basins have been added in this recompilation, and a number of other lakes have been partially recoded to take into account new evidence or additional dating. This represents a marked improvement in the quality of the data bank coverage, particularly since most of the new basins lie in areas previously poorly represented, such as the northern and eastern parts of the continent (Table I and Fig. 2). Despite this improvement, the temporal and spatial distribution of published lake-level information is still uneven. The basins discussed in this paper cover a latitudinal range extending as far north as $56.25^{\circ} \mathrm{N}$. However, approximately $51 \%$ occur between the latitudes $30^{\circ}$ and $40^{\circ} \mathrm{N}$ and $31 \%$ lie within the Great Basin. This pattern is partly determined by the distribution of closed drainage basins (DE MARTONNE and AUFRĖRE, 1928) but is also influenced by the lack of studies from certain areas, particularly Central America and the eastern U.S.A. (BRADBURY, 1982; MARKGRAF and BRADBURY, 1982; HARRISON and METCALFE, 1985).

\section{SPATIAL STRUCTURE OF LAKE LEVELS}

The most distinctive patterns of lake status which occurred during the Holocene over North America are illustrated by Figures 3-6. These patterns and their possible climatological implications are discussed below.

The early Holocene was characterised by increasing aridity in North America, with many lakes falling to intermediate or low levels after the moister conditions characteristic of postglacial times (HARRISON and METCALFE, 1985). This aridity became more pronounced, and by 9,000 yr BP (Fig. 3) widespread low lake levels were registered in both the eastern and western parts of the continent. Conditions remained relatively moist, however, in the central Midwest. Lakes in the American tropics, such as the Basin of Mexico and Lake Pátzcuaro, registered moister conditions at this time. Such conditions could indicate the northward displacement of the Equatorial Trough and increased monsoonal flow into this region. This interpretation is consistent with modelling results which show a significant increase in precipitation associated with enhanced seasonal land-ocean temperature contrasts and stronger monsoonal circulation (KUTZBACH and GUETTER, 1984).

A well-developed arid zone had formed over North America (ca. $32^{\circ}-57^{\circ} \mathrm{N}$ ) by $6,000 \mathrm{yr}$ BP (Fig. 4). This may reflect the further poleward displacement of the frontal zone between the Arctic and Pacific air masses, possibly to north of $56^{\circ} \mathrm{N}$. The general trend towards increasing aridity during the early 
TABLE I

The Oxford Lake-Level Data Bank

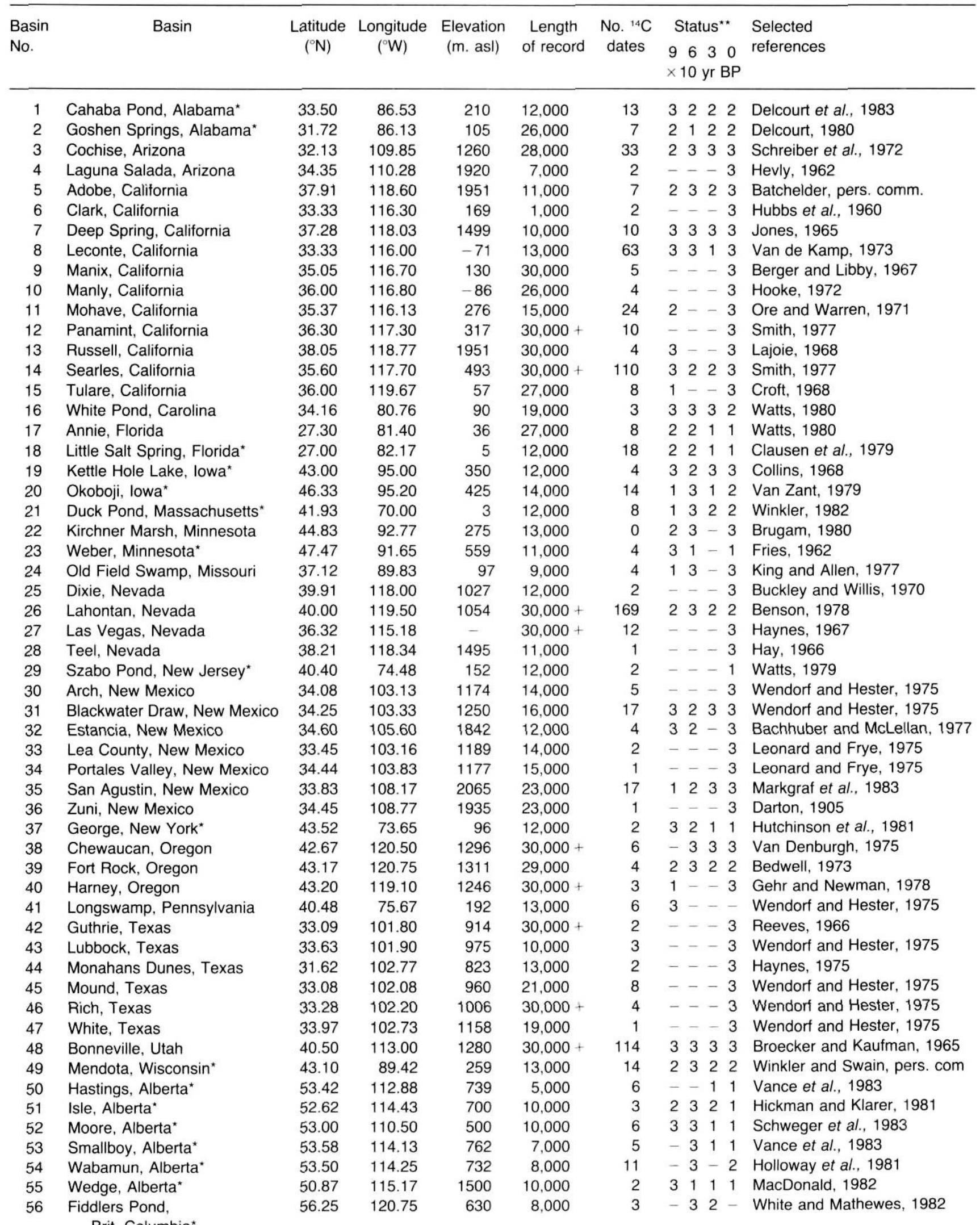




\begin{tabular}{|c|c|c|c|c|c|c|c|c|}
\hline $\begin{array}{l}\text { Basin } \\
\text { No. }\end{array}$ & Basin & $\begin{array}{l}\text { Latitude } \\
\qquad\left({ }^{\circ} \mathrm{N}\right)\end{array}$ & $\begin{array}{l}\text { Longitude } \\
\qquad\left({ }^{\circ} \mathrm{W}\right)\end{array}$ & $\begin{array}{c}\text { Elevation } \\
\text { (m. asl) }\end{array}$ & $\begin{array}{l}\text { Length } \\
\text { of record }\end{array}$ & $\begin{array}{l}\text { No. }{ }^{14} \mathrm{C} \\
\text { dates }\end{array}$ & $\begin{array}{l}\text { Status }^{\star \star} \\
9630 \\
\times 10 \text { yr BP }\end{array}$ & $\begin{array}{l}\text { Selected } \\
\text { references }\end{array}$ \\
\hline 57 & Manitoba, Manitoba & 51.00 & 98.00 & 248 & 12,000 & 9 & 3322 & Teller and Last, 1981 \\
\hline 58 & Elegante Crater, Mexico & 31.80 & 113.52 & 1190 & 17,000 & 2 & ---3 & Damon et al., 1963 \\
\hline 59 & Chichancanab, Mexico* & 19.50 & 88.75 & 38 & 21,000 & 4 & $\begin{array}{llll}3 & 3 & 1 & 3\end{array}$ & Covich and Stuiver, 1974 \\
\hline 60 & México, Mexico & 19.50 & 99.00 & 2240 & $30,000+$ & 26 & $12-1$ & Bradbury, 1971 \\
\hline 61 & Pátzcuaro, Mexico* & 19.58 & 101.58 & 2044 & 18,000 & 6 & 1222 & Watts and Bradbury, 1982 \\
\hline 62 & San Bartolo Playa, Mexico & 29.05 & 111.95 & 5 & 8,000 & 1 & ---3 & Petit-Maire and Casta, 1977 \\
\hline 63 & Upper Lerma, Mexico* & 19.13 & 99.67 & 2575 & 6,000 & 4 & -313 & Metcalfe et al., In press \\
\hline 64 & Fuquene, Colombia & 5.50 & 73.75 & 2580 & $30,000+$ & 0 & $\begin{array}{llll}1 & 1 & 1 & 1\end{array}$ & $\begin{array}{c}\text { Van Geel and Van der } \\
\text { Hammen, } 1973\end{array}$ \\
\hline 65 & Valencia, Venezuela & 10.10 & 67.75 & 402 & 13,000 & 13 & 2212 & Bradbury et al., 1981 \\
\hline 66 & Laguna Ciega, Colombia & 6.50 & 72.30 & 4000 & 25,000 & 0 & $-\cdots$ & Van der Hammen et al., 1981 \\
\hline 67 & El Abra, Colombia & 5.00 & 74.00 & 2570 & $30,000+$ & 8 & $\begin{array}{llll}3 & 3 & 3 & 3\end{array}$ & Schreve-Brinkman, 1978 \\
\hline
\end{tabular}

* Basins added in the 1.3.84 revision of the data bank: ${ }^{\star \star}$ Status classes: $1=$ High, $2=$ Intermediate, $3=$ Low

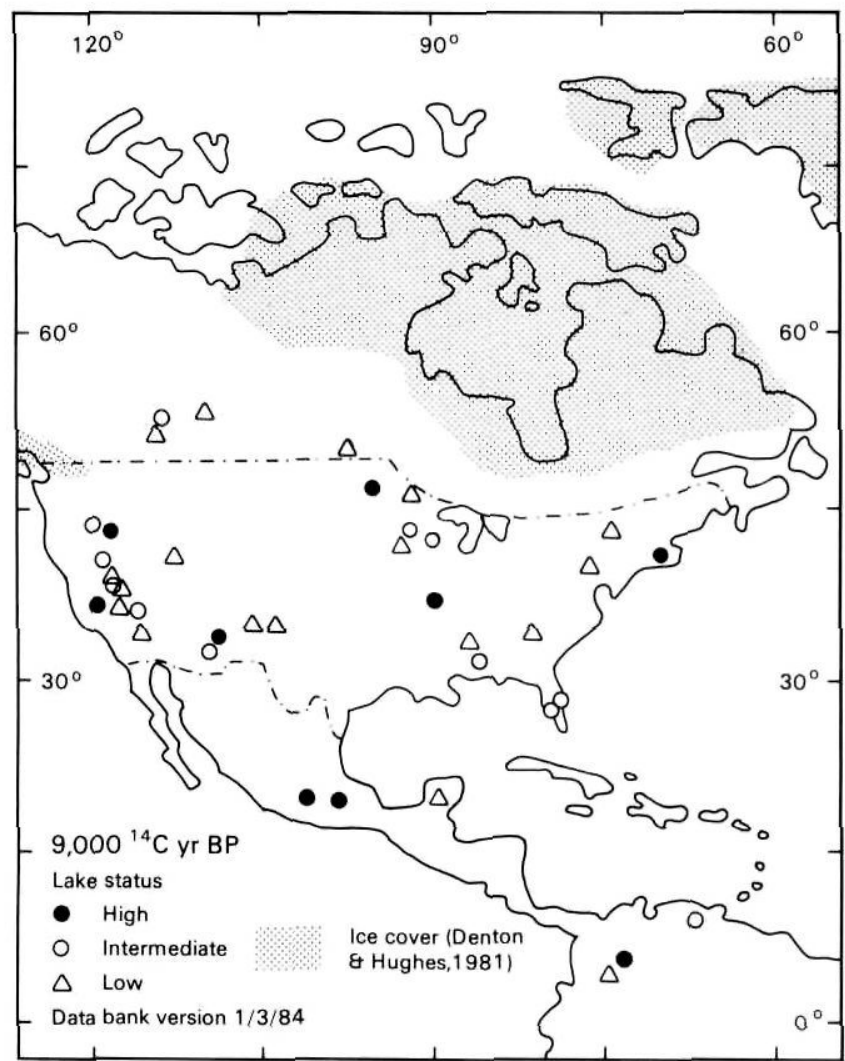

FIGURE 3. Lake status at $9,000 \mathrm{yr}$ BP.

Niveaux lacustres, 9000 ans $B P$.

and mid-Holocene is consistent with independent evidence for eastward expansion of the prairie across the Midwest between 9,000 and 7,000 yr BP (WEBB et al., 1983), which has been interpreted (BARTLEIN et al., 1984) as resulting from the replacement of Arctic air masses over the region by warm, dry Pacific air. The predominance of Pacific air masses over the mid-Continent may have blocked the penetration of moist, tropical maritime air into the interior at this time. Maritime

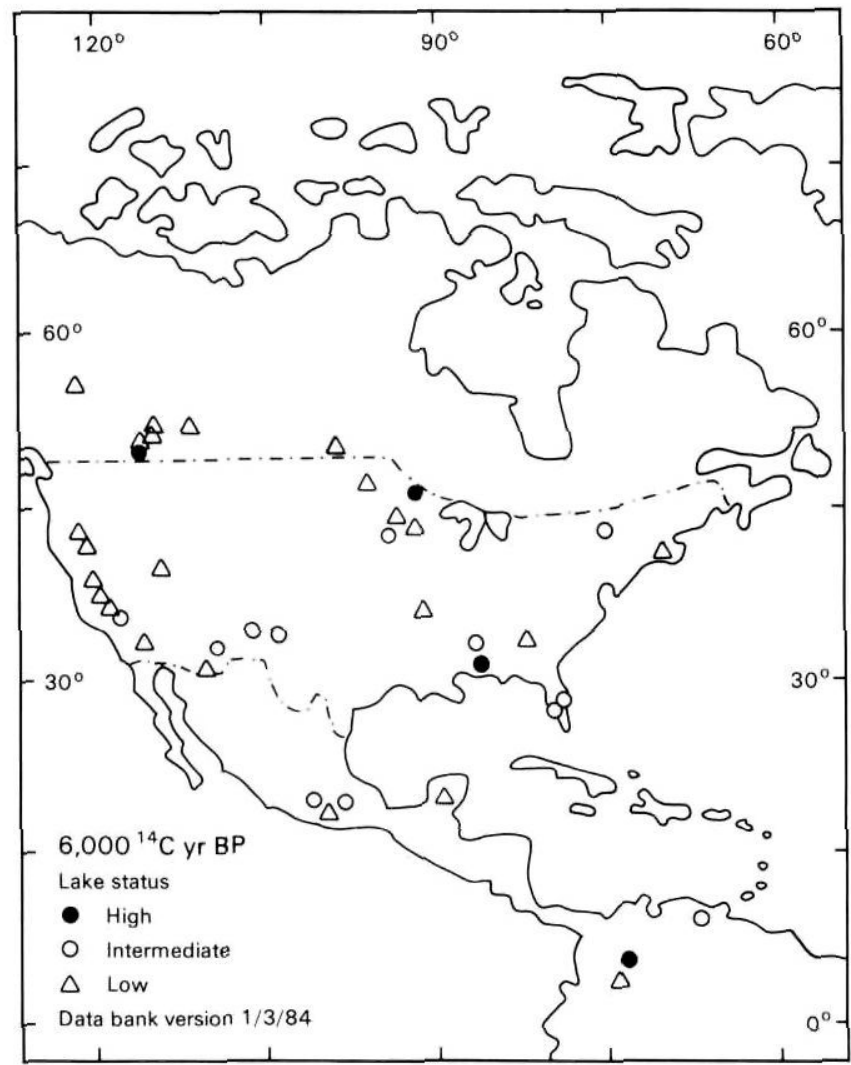

FIGURE 4. Lake status at 6,000 yr BP.

Niveaux lacustres, 6000 ans $B P$.

air mass penetration appears to have been confined to the southeast, where four lakes registered intermediate/high levels. Compared with conditions at present, however, the lakes suggest that flow from the tropics was relatively weak. There are some indications (WEBB et al., 1983; METCALFE and HARRISON, in press; BRADBURY, 1971) that the early Holocene drying phase, illustrated by the pattern at $6,000 \mathrm{yr} \mathrm{BP}$, was in fact most widespread at 7,000 yr BP. 
The present day patterns of both air mass and lake-level distributions were established between 6,000 yr BP and today. By 3,000 yr BP (Fig. 5) a band of high and intermediate lakes had developed between $46^{\circ}$ and $56^{\circ} \mathrm{N}$. This probably reflected the southward displacement of the Arctic Front, at least to around $51^{\circ} \mathrm{N}$ but more probably to its present-day mean position. The Great Basin was still relatively dry, although some lakes adjacent to the Sierra Nevada registered intermediate levels, and hence moister conditions, at this time. Wetter conditions were also experienced along the eastern seaboard, indicating increased penetration of moist tropical air as far north as $45^{\circ} \mathrm{N}$. High lake levels were registered throughout the American tropics and in Florida, which could indicate a stronger trade wind circulation at this time (JAUREGUI, 1979). This more meridional flow would have been encouraged by the establishment of a semi-permanent ridge in the Westerlies over the western part of the Continent and of a trough east of the Rockies (BARTLEIN et al., 1984) typical of the presentday atmospheric circulation. After 3,000 yr BP conditions became more arid within the Great Basin and the American tropics. Thus, the present-day status map (Fig. 6) is characterised by high lake levels along the eastern seaboard and north of $46^{\circ} \mathrm{N}$ and drier conditions in the mid-Continent, the Great Basin and, generally speaking, within the tropics.

\section{TEMPORAL STRUCTURE OF LAKE LEVELS}

Consideration of the lake status maps suggests that there are at least four distinctive regional patterns of lake behaviour

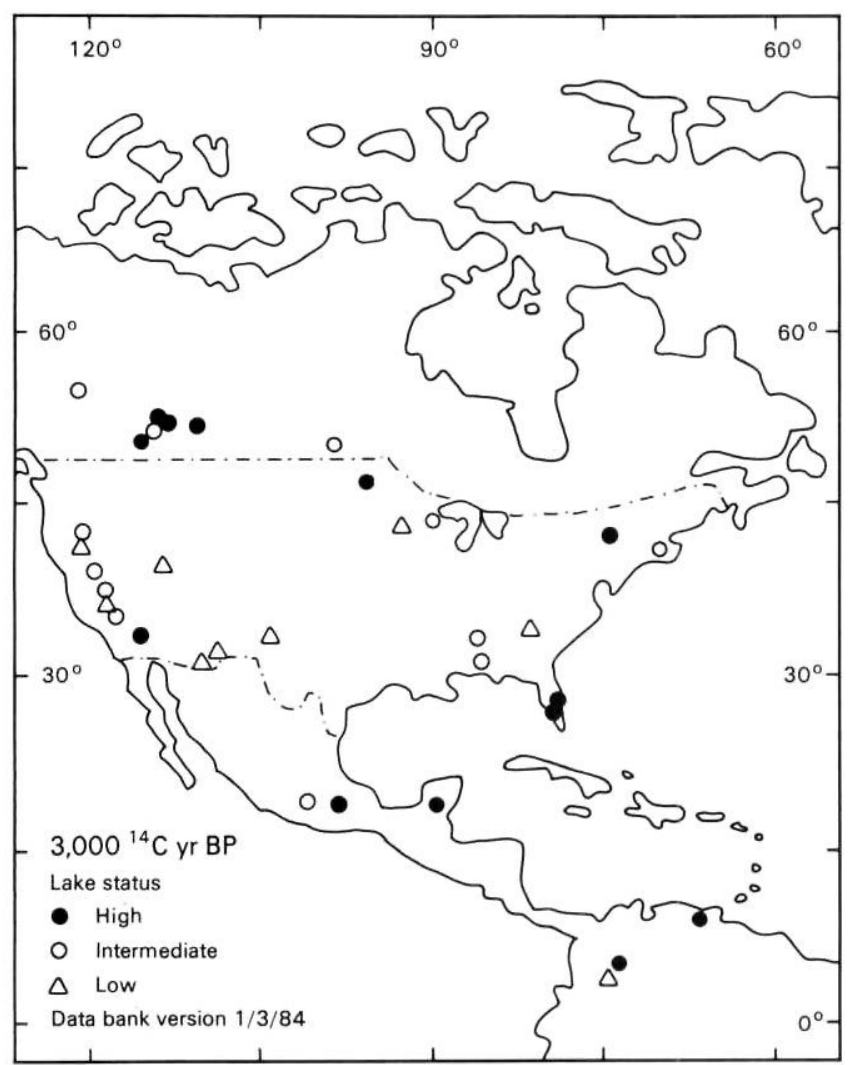

FIGURE 5. Lake status at 3,000 yr BP.

Niveaux lacustres, 3000 ans BP. through time: tropical $\left(0-23.5^{\circ} \mathrm{N}\right)$; eastern midlatitude $\left(23.5^{\circ}-\right.$ $50^{\circ} \mathrm{N}$, east of $\left.100^{\circ} \mathrm{W}\right)$; western midlatitude $\left(23.5^{\circ}-50^{\circ} \mathrm{N}\right.$, west of $\left.100^{\circ} \mathrm{W}\right)$; and northern midlatitude $\left(50^{\circ}-60^{\circ} \mathrm{N}\right)$. Figure 7 illustrates the temporal sequence of lake-level fluctuations in each of these regions between 20,000 yr BP and the present. There is a broad similarity between the eastern midlatitude (Fig. 7c) and tropical (Fig. 7d) patterns, with both experiencing drier conditions around the Glacial Maximum $(20,000$ to $15,000 \mathrm{yr}$ BP). In the eastern midlatitudes two distinct phases of high lake levels were recorded, between 14,000 and 9,000 yr BP and from 4,000 yr BP to the present. These were both registered in the tropics but the pattern there is more complex. The similarity between the two histograms may reflect the importance of Tropical Maritime air as a moisture source in both regions. Thus the earlier phase of high lake levels $(14,000-9,000 \mathrm{yr}$ BP) may reflect increased penetration of moist air from the Gulf of Mexico, as a result of the weakening of zonal circulation and northward displacement of the Arctic Front following the period of rapid recession of the Laurentide Ice Sheet shortly after 14,000 yr BP (BRYSON et al., 1969; PREST, 1969; MAYEWSKI et al., 1981). It is more difficult to interpret the eventful record of the tropical lakes during the early Holocene, but it probably reflects the influence of other air masses on the climate of this region.

The western midlatitude histogram (Fig. 7b) shows a dramatically different pattern from that registered by lakes in the eastern midlatitudes and the tropics, with high lake levels characteristic of the Glacial Maximum and late Glacial, and

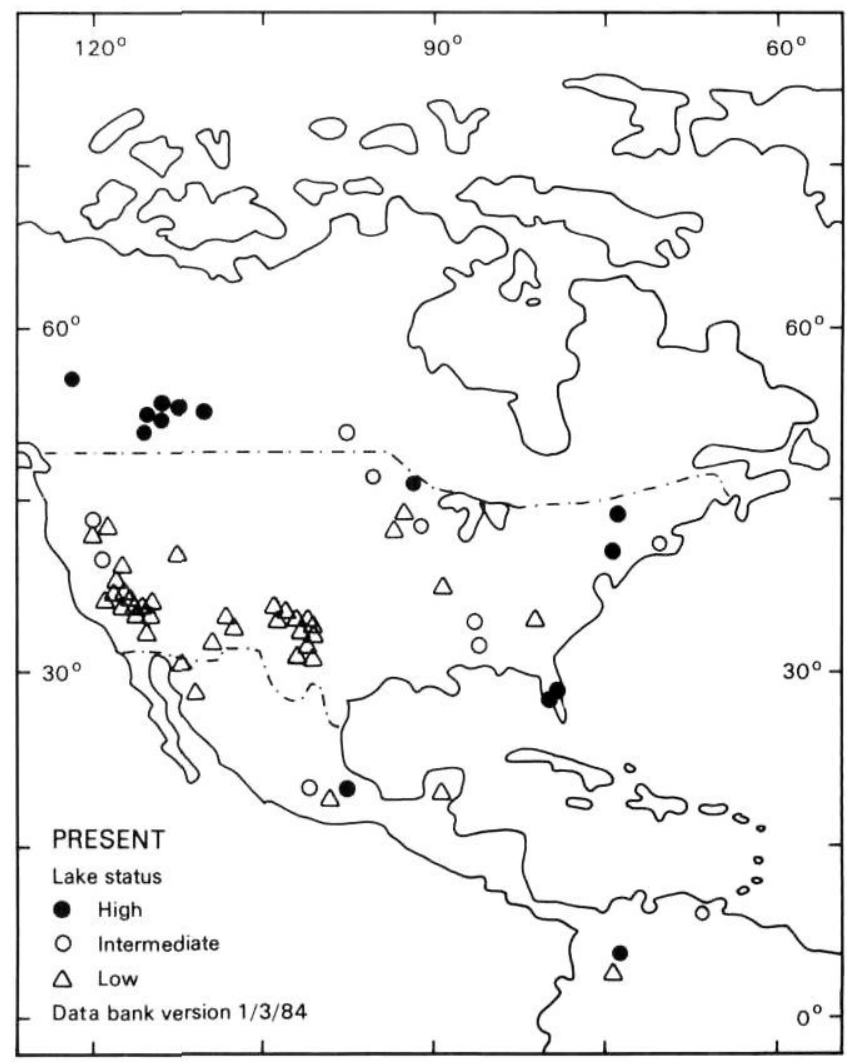

FIGURE 6. Lake status at the present day.

Niveaux lacustres actuels. 


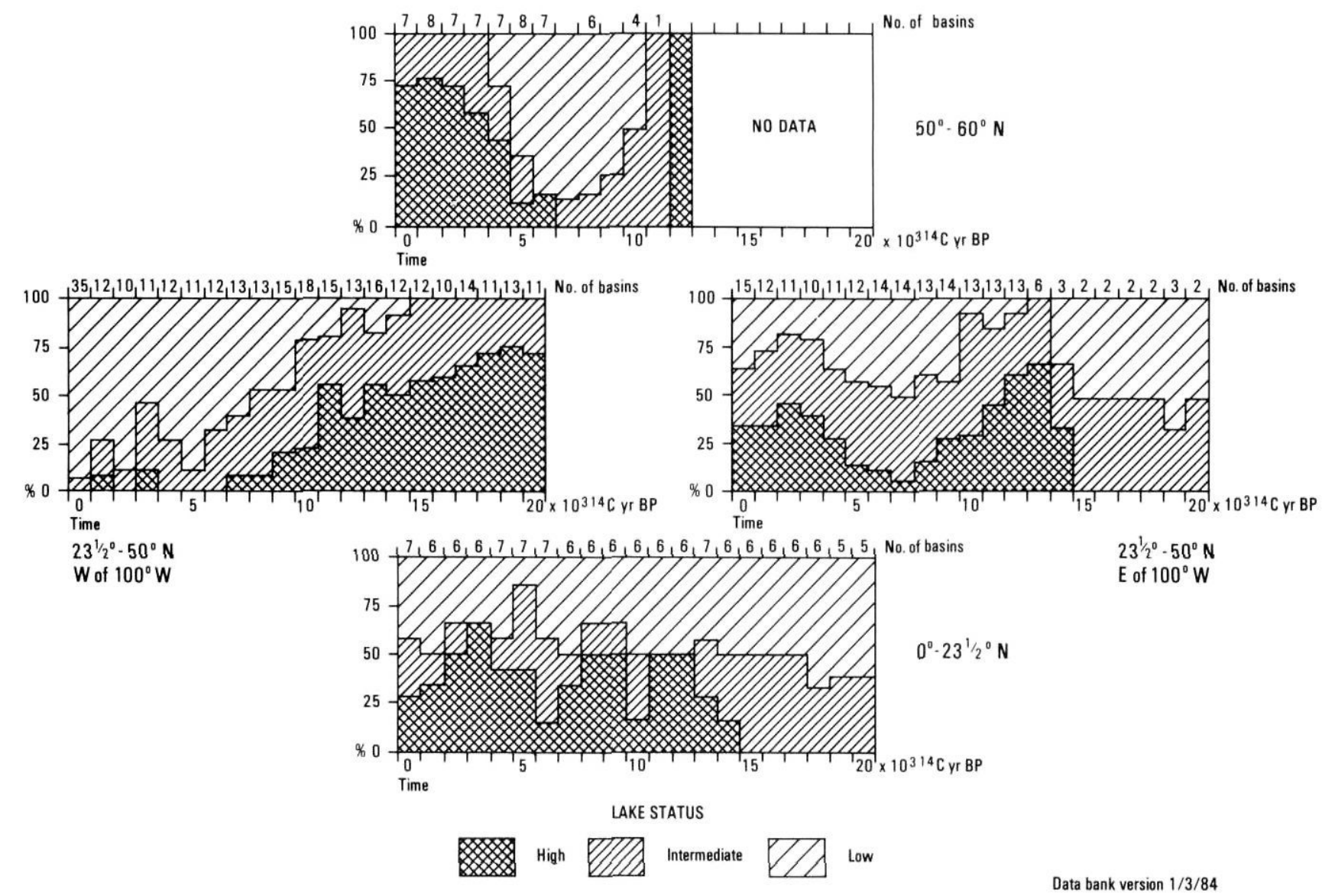

FIGURE 7. Histograms showing temporal variations in lake status for tropical, eastern midlatitude, western midlatitude and northern midlatitude subsets of the Oxford Lake-Level Data Bank.

essentially drier conditions during the early Holocene. A return to moister conditions around 4,000 to $3,000 \mathrm{yr} \mathrm{BP}$ and again at 1,000 yr BP may be indicated by an increase in the number of lakes of intermediate status. The maximum of arid conditions in the western midlatitudes around 6,000 to $5,000 \mathrm{yr}$ BP, occurs slightly after the period of marked low lake levels registered in the northern midlatitudes (Fig. 7a) during the early Holocene $(10,000-7,000 \mathrm{yr} \mathrm{BP})$. It is possible to interpret these temporal patterns as a reflection of the latitudinal migration of the frontal zone between the Arctic and Pacific air masses during the Holocene. Low lake levels after 10,000 yr $\mathrm{BP}$ may indicate the poleward migration of this belt, culminating around $6,000 \mathrm{yr}$ BP when the Arctic Front appears to have reached its most northerly position. High lake levels in the northern midlatitudes from 4,000 yr BP to the present probably reflect the southward migration of this zone to its present position.

\section{CONCLUSIONS}

Lake-level data for North America reveal large fluctuations in water balance over the continent on the time scale of $10^{3} \mathrm{yr}$. Lake-level behaviour exhibits a degree of spatial coherence, which enables regional patterns of lake status to be identified.
Histogrammes illustrant les variations dans le temps des niveaux lacustres pour les sous-ensembles des latitudes tropicales et des moyennes latitudes est, ouest et nord déterminés à partir du Oxford Lake-Level Data Bank.

There are distinctive differences, for example, between the temporal sequences of lake-level fluctuations in the eastern midlatitudes $\left(23.5^{\circ}-50^{\circ} \mathrm{N}\right.$, east of $\left.100^{\circ} \mathrm{W}\right)$ and the western midlatitudes $\left(23.5^{\circ}-50^{\circ} \mathrm{N}\right.$, west of $\left.100^{\circ} \mathrm{W}\right)$. The observed fluctuations in lake behaviour can be seen as a response to changes in the location and intensity of major features of the general circulation and the resultant changes in air mass trajectories over the continent.

The lake-level data provide some support for latitudinal migrations of major features of the general circulation, specifically the Arctic Front and the Equatorial Trough. Around $18,000 \mathrm{yr}$ BP the mean westerly storm track appears to have been centred further south than present at around $35^{\circ}-36^{\circ} \mathrm{N}$ (HARRISON and METCALFE, 1985). Subsequently, the Westerlies migrated northwards reaching their maximum poleward displacement, possibly north of $56^{\circ} \mathrm{N}$, at around $6,000 \mathrm{yr}$ BP. The present day air mass configuration was probably established about $3,000 \mathrm{yr} \mathrm{BP}$. It is more difficult to reconstruct the latitudinal migration of the Equatorial Trough in detail. At $18,000 \mathrm{yr} \mathrm{BP}$, it appears to have been further south than at present, while rising lake levels at $13,000 \mathrm{yr}$ $\mathrm{BP}$ in the tropics probably reflect its migration northward. The limited and sometimes contradictory data for the American 
tropics, however, make it impossible to evaluate the degree to which displacements of the Equatorial Trough were in phase with, and of similar magnitude to, those in midlatitudes.

Superimposed on this pattern of latitudinal migrations, lake levels appear to have responded to changes in the strength and zonality of the atmospheric circulation. Such changes are particularly important through their influence on the behaviour of Tropical Maritime air masses from the Gulf of Mexico. Periods of markedly zonal circulation, for example between 18,000 and $14,000 \mathrm{yr}$ BP, appear to be characterised by reduced penetration of moist tropical air into the continent, leading to low lake levels in both the circum-Gulf tropics and subtropics and along the eastern seaboard of the U.S.A. In contrast, the lake-level pattern at $9,000 \mathrm{yr}$ BP suggests a much less zonal circulation pattern associated with increased monsoonality. Variations in the importance of tropical air masses as a moisture source over the continent,, however, may also reflect changes in the strength of the tropical circulation. These may be the result of variations in land and sea-surface temperature, and pressure gradients.

An understanding of the regional patterns of lake-level behaviour over North America requires an appreciation that the palaeo-atmospheric circulation was at least as inherently complex as that of the present day. Although a reasonable level of explanation of the observed patterns has been achieved by consideration of air mass trajectories, we feel that a more detailed analysis of the associated weather systems is necessary to understand fully the observed changes in the circulation.

\section{ACKNOWLEDGEMENTS}

We would like to thank J. Kutzbach, P. Bartlein, G. Spaulding P.J. Lamb and M. Kuhn for their helpful comments on an earlier version of this paper and F.A. Street-Perrott, for her encouragement and suggestions. We are grateful to $\mathrm{H}$. Wright for his review of this paper and to T. Webb III for his stimulating and amusing advice. Financial support for this research was provided by U.S. Department of Energy Contract No. DEAC02-79EV10097 to T. Webb III at Brown University (S.P.H.) and through a N.E.R.C. studentship (S.E.M.). Financial assistance to enable S.P.H. to attend the conference at Sherbrooke was given by the Royal Meteorological Society of Great Britain.

\section{REFERENCES}

BACHHUBER, F.W. and McLELLAN, W.A. (1977): Paleoecology of marine foraminifera in the pluvial Estancia valley, Central New Mexico, Quaternary Research, Vol. 7, p. 254-267.

BARTLEIN, P.J., WEBB III, T and FLERI, E. (1984): Holocene climatic change in the northern Midwest: Pollen-derived estimates, Quaternary Research, Vol. 22, p. 361-374.

BEDWELL, S.F. (1973): Fort Rock Basin: Prehistory and Environment, University of Oregon Press, Eugene, $189 \mathrm{p}$.

BENSON, L.V. (1978) : Fluctuation in the level of pluvial Lake Lahontan during the last 40,000 years, Quaternary Research, Vol. 9, p. 300318.
BERGER, R. and LIBBY, W.F. (1967): UCLA radiocarbon dates VI, Radiocarbon, Vol. 9, p. 477-504.

BRADBURY, J.P. (1971): Paleolimnology of Lake Texcoco, Mexico, Limnology and Oceanography, Vol. 16, p. 180-200.

(1982): Holocene chronostratigraphy of Mexico and Central America, Striae, Vol. 16, p. 46-48.

BRADBURY, J.P., LEYDEN, B., SALGADO-LABOURIAU, M.L., LEWIS Jnr. W.M., SCHUBERT, C., BINFORD, M.W., FREY D.G., WHITEHEAD, D. R. and WEIBEZAHN, F.H. (1981) : Late Quaternary environmental history of Lake Valencia, Venezuela, Science, Vol. 214, p. 1299-1305.

BROECKER, W.S. and KAUFMAN, A. (1965): Radiocarbon chronology of Lake Lahontan and Lake Bonneville II, Great Basin, Geological Society of America Bulletin, Vol. 76, p. 537-566.

BRUGAM, R.B. (1980): Postglacial diatom stratigraphy of Kirchner Marsh, Minnesota, Quaternary Research, Vol. 13, p. 133-146.

BRYSON, R.A. (1966): Air masses, streamlines and the Boreal forest, Geographical Bulletin, Vol. 8, p. 228-269.

BRYSON, R.A. and HARE, F.K. (1974): Climates of North America, World Survey of Climatology II, Amsterdam, Elsevier Scientific Publishing Company.

BRYSON, R.A. and WENDLAND, W.M. (1967): Tentative climatic patterns for some late glacial and post-glacial episodes in central North America, in Life, Land and Water: Proceedings of the Conference on Environmental Studies of the Glacial Lake Aqassiz region, 1966, Manitoba University, Department of Anthropology Occasional Paper 1, 271-298.

BRYSON, R.A., WENDLAND, W.M., IVES, J.D. and ANDREWS, J.T. (1969): Radiocarbon isochrones on the disintegration of the Laurentide Ice Sheet, Arctic and Alpine Research, Vol. 1, p. 114.

BUCKLEY, J.D. and WILLIS, E.H. (1970): Isotopes' radiocarbon measurements VIII, Radiocarbon, Vol. 12, p. 87-129.

CLAUSEN, C.J., COHEN, A.D., EMILIANI, C., HOLMAN, J.A. and STIPP, J.J. (1979): Little Salt Spring, Florida: a unique underwater site, Science, Vol. 203, p. 609-614.

COLLINS, G.B. (1968): Implications of Diatom Succession in PostGlacial Sediments from Two Sites in Northern lowa, Unpublished $\mathrm{PhD}$. thesis, lowa State University, Ames.

COVICH, A. and STUIVER, M. (1974): Changes in oxygen-18 as a measure of long-term fluctuations in tropical lake levels and molluscan populations, Limnology and Oceanography, Vol. 19, p. 682691.

CROFT, M.G. (1968): Geology and radiocarbon ages of Late Pleistocene lacustrine clay deposits, southern part of San Joaquin Valley, California, U.S. Geological Survey Professional Paper, 600B, B151-B156.

DAMON, P.E., LONG, A. and SIGALOVE, J.J. (1963): Arizona radiocarbon dates IV, Radiocarbon, Vol. 5, p. 283-301.

DARTON, N.H. (1905): The Zuni Salt Lake, Journal of Geology, Vol. 13, p. 185-193.

DELCOURT, P.A. (1980): Goshen Spring: Late Quaternary vegetation record for southern Alabama, Ecology, Vol. 61, p. 371-386.

DELCOURT, H.R., DELCOURT, P.A. and SPIKER, E.C. (1983) : A 12,000 year record of forest history from Cahaba Pond, St. Clair County, Alabama, Ecology, Vol. 64, p. 874-887.

DENTON, G.H. and HUGHES, T.J., (1981): The Last Great Ice Sheets, New York, Wiley-Interscience, 484 p. 
FRIES, M. (1962): Pollen profiles of Late Pleistocene and recent sediments at Weber Lake, northeastern Minnesota, Ecology, Vol. 43, p. 295-308.

GEHR, K.D. and NEWMAN, T.M. (1978): Preliminary note on the Late Pleistocene geomorphology and archaeology of the Harney Basin, Oregon, The Ore Bin, Vol. 40, p. 165-170.

HARRISON, S.P. and METCALFE, S.E. (1985): Spatial variations in lake levels since the Last Glacial Maximum in the Americas North of the Equator, in Zeitschrift für Gletscherkunde und Glazialgeologie, Vol 21.

HAY, R.L. (1966): Zeolites and zeolitic reactions in sedimentary rocks, Geological Society of America Special Paper, 85, $130 \mathrm{p}$.

HAYNES, C.V. (1967): Quaternary geology of the Tule Springs area, Clark County, Nevada, in H.M. WORMINGTON and D. ELLIS, (eds), Pleistocene Studies in Southern Nevada, Nevada State Museum of Anthropology Papers, 213, Carson City, Nevada, p. 15-104.

(1975): Pleistocene and recent stratigraphy, in F. WENDORF and J.J. HESTER (eds.), Late Pleistocene Environments of the Southern High Plains, Fort Bergwin Research Publication, 9, p. 57-96.

HEVLY, R.H. (1962): Paleocology of Laguna Salada, in MARTIN, P.S. et al. (eds), Chapters in the prehistory of Arizona II, Chicago Natural History Museum Fieldiana (Anthropology) Vol. 55, p. 171187.

HICKMAN, M. and KLARER, D.M. (1981): Paleolimnology of Lake Isle, Alberta, Canada, Archiwum Hydrobiologii, Vol. 91, p. 490508.

HOLLOWAY, R.G., BRYANT, V.M. and VALASTRO, S. (1981): A 16,000 year pollen record from Lake Wabamun, Alberta, Canada, Palynology, Vol. 5, p. 195-208.

HOOKE, R.B. (1972): Geomorphic evidence for late Wisconsin and Holocene deformation, Death Valley, California, Geological Society of America Bulletin, Vol. 83, p. 2073-2098.

HUBBS, C.L., BIEN, G.S. and SUESS, H.E. (1960): La Jolla natural radiocarbon measurements I, Radiocarbon Vol. 2, p. 197-223.

HUTCHINSON, D.R., FERREBEE, W.M., KNEBEL, H.J., WOLD, R.J. and ISACHSEN. Y.W. (1981): The sedimentary framework of the southern basin of Lake George, New York, Quaternary Research, Vol. 15, p. 44-61.

JAUREGUI, O.E. (1979): Algunos aspectos de las fluctuaciones pluviométricas en México en los ultimos cien an̈os, Boletin del Instituto de Geografia, U.N.A.M., Vol. 9: p. 39-64.

JONES, B.F. (1965): The hydrology and mineralogy of Deep Springs Lake, Inyo County, California, U.S. Geological Survey Professional Paper 502-A, A56p.

KING, J.E. and ALLEN, W.H. (1977): A Holocene vegetation record from the Mississippi River Valley, Quaternary Research, Vol. 8, p. 307-323.

KUTZBACH, J.E. and GUETTER, P.J. (1984): The sensitivity of monsoon climates to orbital parameter changes for 9000 years BP. Experiments with the NCAR General Circulation Model, in A. BERGER and J. IMBRIE (eds), Milankovitch and Climate, Dordrecht, D. Reidel, p. 801-820.

LAJOIE, K. (1968): Quaternary Stratigraphy and Geologic History of Mono Basin, Eastern California, Ph.D. Dissertation, University of California, Berkeley.
LEONARD, A.B. and FRYE, J.C. (1975): Pliocene and Pleistocene deposits and molluscan faunas, east-central New Mexico, New Mexico Bureau of Mines and Mineral Resources, Memoires, Vol. 30, $44 \mathrm{p}$.

MacDONALD, G.M. (1982) : Late Quaternary paleoenvironments of the Morley Flats and Kananaskis Valley of southwest Alberta, Canadian Journal of Earth Sciences, Vol. 19, p. 23-35.

MARKGRAF, V. and BRADBURY, J.P. (1982): Holocene climatic history of South America, Striae, Vol. 16, p. 40-45.

MARKGRAF, V., BRADBURY, J.P., FORESTER, R.M., McCOY, W., SINGH, G. and STERNBERG, R. (1983): Paleoenvironmental reassessment of the 1.6 million year old record from San Agustin Basin, New Mexico, New Mexico Geological Society Guidebook, 34th Field Conference, p. 291-297.

MARTONNE, E. De and AUFRĖRE, L. (1928) : L'extension des régions privées de l'écoulement vers l'océan, Annales de Géographie, Vol. 38, p. 1-24.

MAYEWSKI, P.A., DENTON G.H. and HUGHES, T.J. (1981): Late Wisconsin Ice Sheets in North America, in G.H. DENTON and T.J. HUGHES (eds), The Last Great Ice Sheets, New York, John Wiley \& Sons, p. 67-178.

METCALFE, S.E. and HARRISON, S.P. (in press): Reconstrucciones preliminares de cambios ambientales durante el cuaternario superior indicada par los depositos lacustres riberenos de la cuenca de Zacapu, Michoacán, Boletín del Instituto de Geografia, U.N.A.M.

METCALFE, S.E., STREET-PERROTT, F.A., PERROTT, R.A. and HARKNESS, D.D. (in press): Environmental changes during the Late Quaternary in the Upper Lerma Basin, Estado de México, in Proceedings of the Eighth International Diatom Symposium, Paris 1984.

ORE, H.T. and WARREN, C.N. (1971): Late Pleistocene-Early Holocene geomorphic history of Lake Mojave, California, Geological Society of America Bulletin, Vol. 82, p. 2553-2562.

PETIT-MAIRE, N. and CASTA, L. (1977): Un paléolac du nord-ouest mexicain: la Playa San Bartolo, in Recherches françaises sur le Quaternaire, INQUA 1977, Bulletin de l'Association française pour l'Étude du Quaternaire, 1977-1, No. 50 p. 303-322.

PREST, V.K. (1969): Retreat of Wisconsin and Recent ice in North America, Ottawa, Geological Survey of Canada, Map 1257A.

REEVES, C.C. (1966): Pluvial lake basins of West Texas, Journal of Geology, Vol. 74, p. 269-291.

SCHREIBER, J.F. Jr., PINE, G.L., PIPKIN, B.W., ROBINSON, R.C. and WILT, J.C. (1972): Sedimentologic studies in the Willcox Playa Area, Cochise County, Arizona, in C.C. REEVES, Jr. (ed), Playa Lakes Symposium, International Center for Arid and Semiarid Land Studies (ICASALS) Publication, Vol. 4, Lubbock, Texas, p. $133-184$.

SCHREVE-BRINKMAN, E.J. (1978): A palynological study of the Upper Quaternary sequence in the El Abra corridor and rock shelters, Colombia, Palaeogeography, Palaeoclimatology, Palaeoecology, Vol 25, p. 1-109.

SCHUILING, R.D. (1977): Source and composition of lake sediments, in H.L. GOTTERMAN (ed.), Interactions between Sediments and Freshwater, Wageningen, PUDOC, p. 12-18.

SCHWEGER, C., HABGOOD, T. and HICKMAN, M. (1983): Late Glacial Holocene climatic changes of Alberta: the record from lake sediment studies, in The Impacts of Climatic Fluctuations on Alberta's Resources and Environment, Atmospheric Environment Service, Environment Canada, Edmonton Report, WAES-1-81. p. 47-60. 
SMITH, G.I. (1977): Paleoclimatic record in the upper Quaternary sediments of Searles Lake, California, U.S.A., Paleolimnology of Lake Biwa and the Japanese Pleistocene, Vol. 4, p. 577-604.

SMITH, G.I. and STREET-PERROTT, F.A. (1983): Pluvial lakes of the Western United states, in S.C PORTER (ed.) Late Quaternary Environments of the United States. Volume 1. The Late Pleistocene, Minneapolis, University of Minnesota Press, p. 190-212.

STREET, F.A. and GROVE, A.T. (1976): Environmental and climatic implications of Late Quaternary lake-level fluctuations in Africa, Nature, Vol. 261, p. 385-390.

(1979): Global maps of lake-level fluctuations since 30,000 BP, Quaternary Research, Vol. 12, p. 83-118.

STREET-PERROTT, F.A. and HARRISON, S.P. (1984): Temporal variations in lake levels since $30,000 \mathrm{yr} B P-$ an index of the global hydrological cycle, American Geophysical Union, Maurice Ewing Series, Vol. 5, p. 118-129.

(1985): Lake-levels and climate reconstruction, in A.D. HECHT, (ed), Paleoclimate Analysis and Modeling, New York, John Wiley, p. 291-340.

STREET-PERROTT, F.A. and ROBERTS, N. (1983): Fluctuations in closed lakes as an indicator of past atmospheric circulation patterns, in F.A. STREET-PERROTT, M. BERAN and R.A.S. RATCLIFFE (eds.), Variations in the Global Water Budget, Dordrecht, D. Reidel, p. 331-345.

STREET-PERROTT, F.A., ROBERTS, N. and METCALFE, S.E. (1985): Geomorphic implications of Late Quaternary hydrological and climatic changes in the northern hemisphere tropics, in I. DOUGLAS and T. SPENCER (eds), Geomorphology and Environmental Change and Tropical Geomorphology, London, George Allen and Unwin, p. 165-183.

TELLER, J.T. and LAST, W.M. (1981): Late Quaternary history of Lake Manitoba, Canada, Quaternary Research, Vol. 16, p. 97116.

VANCE, R.E., EMERSON, D. and HABGOOD, T. (1983): A midHolocene record of vegetative change in central Alberta, Canadian Journal of Earth Sciences, Vol. 20, p. 364-376.

VAN DE KAMP, P. C. (1973): Holocene continental sedimentation in the Salton Basin, California: a reconnaissance, Geological Society of America Bulletin, Vol. 84, p. 827-848.
VAN DENBURGH, A.S. (1975): Solute balance at Abert and Summer Lakes, South-central Oregon, U.S. Geological Survey Professional Paper, Vol. 502-C, C1-C29.

VAN DER HAMMEN, T., BARELDS, J., DE JONG, $H$. and DE VEER, A.A. (1981): Glacial sequence and environmental history in the Sierra Nevada del Cucoy, Colombia, Palaeogeography, Palaeoclimatology, Palaeoecology, Vol. 32, p. 247-340.

VAN GEEL, B. and VAN DER HAMMEN, T. (1973): Upper Quaternary vegetation and climatic sequence of the Fuquene area (Eastern Cordillera, Colombia), Palaeogeography, Palaeoclimatology, Palaeoecology, Vol. 4, p. 9-92.

VAN ZANT, K. (1979): Late glacial and postglacial pollen and plant macrofossils from Lake West Okoboji, northwestern lowa, Quaternary Research, Vol. 12, p. 358-380.

WATTS, W.A. (1979): Late Quaternary vegetation of Central Appalachia and the New Jersey coastal plain, Ecological Monographs, Vol. 49, p. 427-469.

(1980): Late Quaternary vegetation history at White Pond on the Inner Coastal Plain of South Carolina, Quaternary Research, Vol. 13, p. 187-199.

WATTS, W.A. and BRADBURY, J.P. (1982): Paleoecological studies at Lake Pátzquaro on the West-Central Mexican Plateau and at Chalco in the Basin of Mexico, Quaternary Research, Vol. 17, p. 56-70.

WEBB III, T., CUSHING, E.J. and WRIGHT, Jr., H.E. (1983): Holocene Changes in the Vegetation of the Midwest, in H.E. WRIGHT Jr. (ed), Late Quaternary Environments of the United States, Minneapolis, University of Minnesota.

WENDLAND, W.M. and BRYSON, R.A. (1981): Northern Hemisphere airstream regions, Monthly Weather Review, Vol. 109, p. 255270.

WENDORF, F. and HESTER, J.J. (eds) (1975): Late Pleistocene Environments of the Southern High Plains, Fort Burgwin Research Center Publication, Vol. 9.

WHITE J.M. and MATHEWES, R.W. (1982): Holocene vegetation and climatic change in the Peace River district, Canada, Canadian Journal of Earth Sciences, Vol. 19, p. 555-570.

WINKLER, M.J. (1982) : Late-glacial and Postglacial Vegetation History of Cape Cod and the Paleolimnology of Duck Pond, South Wellfleet, Massachusetts, Unpublished MSc. thesis, University of WisconsinMadison, $118 \mathrm{p}$. 